\title{
Preface: Tyranny Comes Home
}

In August 20I4 a police officer in Ferguson, Missouri, shot and killed teenager Michael Brown, leading to widespread protests throughout the city. The response from the local police to the protests drew national attention to the equipment and tactics employed. Officers dressed in full military garb, including camouflage uniforms, body armor, helmets, and gas masks, confronted the protestors. The officer's vehicles included Ballistic Engineered Armored Response Counter Attack Trucks (BearCats), a mine-resistant variant of which is used abroad by the military. In addition to their dress and vehicles, police were armed with military-grade rifles capable of hitting long-distance targets. Who can forget the picture of a sniper in full military gear perched atop a tactical operations vehicle pointing his rifle with a high-powered scope at the protestors?

These and other images from Ferguson could easily have come from U.S. military operations in Afghanistan or Iraq. Police officers tasked with protecting and serving the local community looked much more like soldiers tasked with finding and destroying an enemy in a war zone. The police response shined a spotlight on the militarization of domestic policing, a national phenomenon that had been unfolding quietly for decades.

More broadly, the events in Ferguson illustrate how the mentality, methods, and gear of war can return from abroad and affect domestic life. The purpose of this book is to provide insight into this phenomenon. We offer a general framework for how approaches and tools that have been developed for and deployed in foreign interventions return home and, in the process, threaten domestic liberties. This helps explain not just the militarization of police but also the domestic use of surveillance, drones, and torture. In doing so it sheds light on an overlooked cost of a proactive, interventionist foreign policy. 
This page intentionally left blank 